\title{
Macular exanthema in a child with rotavirus gastroenteritis. A case report
}

\author{
Ahmet Zulfikar Akelma, M.D. ${ }^{a}$; Mehmet Nevzat Cizmeci, M.D. ${ }^{b}$; Emin Mete, M.D. ${ }^{a}$; \\ Dilsad Dilara Malli, M.D. ${ }^{b}$; Seval Erpolat, M.D. ${ }^{c}$; Fatma Mujgan Sonmez, M.D. ${ }^{b}$
}

\begin{abstract}
Apart from gastroenteritis, rotavirus has been rarely implicated with some cutaneous disorders such as generalized maculopapular exanthema, infantile acute hemorrhagic edema and Gianotti-Crosti syndrome. We report a 30-month old toddler boy who developed erythematous macular skin eruptions during the course of rotavirus gastroenteritis. To our knowledge, this is the first case in the literature reporting rotavirusrelated macular erythematous lesions in a pediatric patient. We therefore would like to share our experience, to keep rotavirus infection in the differential diagnosis of children with gastroenteritis and erythematous eruption.

Keyword: Rotavirus, gastroenteritis, child, erythema.
\end{abstract}

http:/ /dx.doi.org/10.5546/aap.2014.eng.e53

\section{INTRODUCTION}

Rotavirus is the leading cause of acute gastroenteritis in children. In developing countries, rotavirus-related diarrhea and vomiting, together, are the major causes of severe dehydration and eventual death in children. ${ }^{1-3}$ Apart from gastroenteritis, rotavirus has also been implicated with several systemic disorders such as elevated transaminase, ${ }^{4}$ convulsion, ${ }^{5,6}$ encephalitis, ${ }^{7}$ pneumonia, ${ }^{8}$ disseminated intravascular coagulation, ${ }^{9}$ hemophagocytic lymphohistiocytosis, ${ }^{10}$ nephritis in children with immunodeficiency ${ }^{11}$ and also with several cutaneous disorders such as generalized maculopapular exanthema, ${ }^{12}$ infantile acute hemorrhagic edema ${ }^{13}$ and Gianotti-Crosti syndrome. ${ }^{14}$ Rotavirus-related exanthem, however, has seldom been reported. ${ }^{12}$ Herein,

a. Division of Pediatric Allergy.

b. Department of Pediatrics.

c. Department of Dermatology.

Fatih University Medical School, Ankara, Turkey.

Correspondencia:

A. Zulfikar Akelma, M.D.: akelma@gmail.com

Conflicto de intereses: ninguno que declarar.

Recibido: 24-5-2013

Aceptado: 5-12-2013 we report a 30-month old male toddler who developed erythematous macular skin eruptions during the course of rotavirus gastroenteritis.

\section{Case Report}

A 30-month old male toddler was brought to the pediatric outpatient clinic with gastrointestinal symptoms and skin eruptions. His complaints started two days ago with diarrhea and vomiting and were followed, the next day, by an erythematous eruption which began around his cheeks, and spreaded peripherally to the lateral aspect of the thighs and both of his arms. No fever, bloody diarrhea, itching or papular lesions were reported. The patient did not have any chronic disease or history of a drug use. Because rotavirus vaccine is still not introduced into Turkey's national immunization schedule the child was not vaccinated against rotavirus. The patient was living with his school-age sibling and was not enrolled in a kindergarten. On examination his weight and height were $12 \mathrm{~kg}$ (10-25 percentile) and $89 \mathrm{~cm}$ (25-50 percentile), respectively. The child appeared dehydrated and physical examination revealed the following results: body temperature: $37.2^{\circ} \mathrm{C}$, respiratory rate: $24 / \mathrm{min}$, peak heart rate: $100 / \mathrm{min}$ and blood pressure: $80 / 50 \mathrm{mmHg}$. His mouth was dry, the color of mucous membrane was pale and eyeballs were sunken along with an apparently decreased skin turgor and tonus. His consciousness was clear and he did neither have hepato-splenomegaly nor lymphadenopathy. On auscultation he had hyperactive bowel sounds. On dermatologic examination he had symmetrically distributed and morbiliform widespread exanthems around his cheeks, on the anterior aspect of his chest and over both his forearms and the lateral aspect of his thighs and feet. The scalp, his back, proximal arms and legs were free of lesions (Figure 1). Due to his dehydration and impaired nutrition status, he was hospitalized and was supported with intravenous fluids.

Laboratory results were as follows: hemoglobin: $11.8 \mathrm{~g} / \mathrm{dL}$ (normal range: 11.5-15.5), 
FIGURE 1. Macular erythematous eruption observed in (a) the forearm, (b) the feet and (c) lateral aspect of the gluteal regions

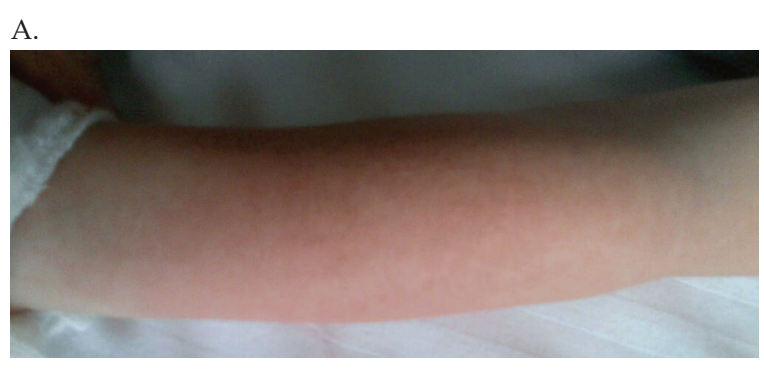

B.

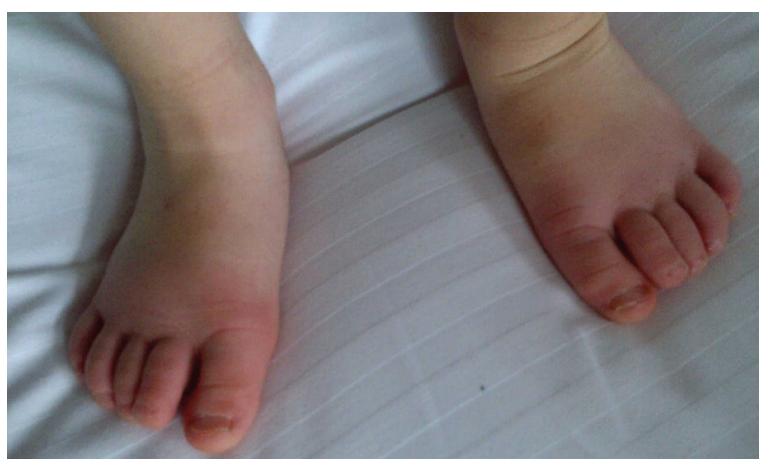

C.

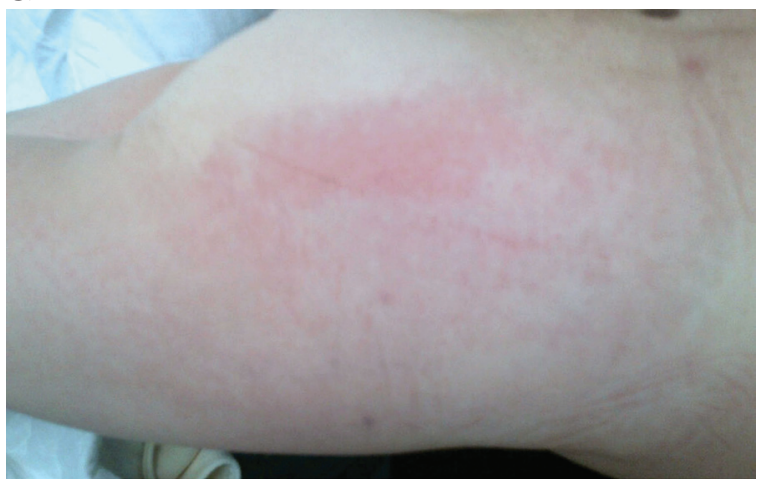

white blood cell count: $6500 / \mathrm{mm}^{3}$ (normal range: $6000-17500$ ) (32\% neutrophils, $54 \%$ lymphocytes, $10 \%$ monocytes, $2 \%$ basophils, $2 \%$ eosinophils), thrombocyte count: $172000 / \mathrm{mm}^{3}$ (normal range: 150 000-400 000), $C$ reactive protein: 2.61 $\mathrm{mg} / \mathrm{L}$ (normal range: $0-5$ ), blood urea nitrogen: $31 \mathrm{mg} / \mathrm{dL}$ (normal range: 5-18). The biochemical parameters including serum sodium, potassium, creatinine, aspartate aminotransferase, alanine aminotransferase, total bilirubin, and direct bilirubin was normal (Table 1). Urinalysis revealed a density of 1030, while microscopic examination and culture of the urine was unremarkable.
The rapid group A Streptococcus test and the throat culture test were both negative. While the IgM rubella, rubeola, cytomegalovirus and Epstein Barr virus antibodies were negative, IgG titers were positive. Rotavirus and adenovirus antigen identification were performed by immunochromatography (Operon S.A., Zaragoza, Spain) in fresh stool specimens. Rotavirus antigen was identified in two consecutive specimens. Stool cultures were negative for potential causative bacterial agents, such as Salmonella, Shigella, and Campylobacter. Initial assessment for serum Antistreptolysin-O titer revealed 161 Todd units (120-160), and repeat assessment performed two weeks later revealed 121 Todd units. Erythematous lesions resolved completely within 4 days without any treatment.

\section{DISCUSSION}

Although rotavirus frequently replicates at the surface epithelial cells of the small intestinal villi, where the infection usually tends to be limited, it may also cause viremia. ${ }^{15}$ Therefore, systemic manifestations including cutaneous disorders, although rare, may be associated with rotavirus infection. ${ }^{16}$ Ruzicka et al., ${ }^{12}$ reported the first case of a patient with signs of hepatitis and generalized maculo-papular exanthema which developed one week after his two sons had suffered from rotavirus gastroenteritis. Rotavirus antibody at titers of 1:256 and 1:512 were identified from the patient's serum. Additionally, Di Lernia ${ }^{14}$ has reported rotavirus-related Gianotti-Crosti syndrome in a 7-month old child and also, in a separate report, acute infantile hemorrhagic edema following rotavirus infection in a 11-month old girl. ${ }^{13}$

Our patient presented with erythematous macular skin eruptions, acute gastroenteritis and dehydration. Etiologic examinations performed twice, revealed rotavirus antigen in the stool samples. Because the eruptions were judged to be of a specific nature, further etiologic assessment was performed and neither viral pathogens nor streptococcus antigens were found to be positive. Although the clinical appearance of the eruption was not typically allergic in character, antihistaminic response was tested, and found to be unremarkable. Apart from eruption, no clinic or laboratory findings relevant to any potential systemic diseases was identified.

In brief, given the fact that the skin lesions observed in our patient developed concurrently with gastroenteritis, that rotavirus was positive 
TABLE 1. Laboratory features of the patient

\begin{tabular}{|c|c|c|}
\hline Laboratory features & Value & Normal Range \\
\hline White blood cell (count/ $\mathrm{mm}^{3}$ ) & 6500 & $6000-17500$ \\
\hline Neutrophils (\%) & 32 & \\
\hline Lymphocytes (\%) & 54 & \\
\hline Monocytes (\%) & 10 & \\
\hline Basophils (\%) & 2 & \\
\hline Eosinophils (\%) & 2 & \\
\hline Hemoglobin (g/dL) & 11.8 & $11.5-15.5$ \\
\hline Platelets (count/ mm³) & 172000 & $150000-400000$ \\
\hline $\mathrm{C}$ reactive protein $(\mathrm{mg} / \mathrm{L})$ & 2.61 & $0-5$ \\
\hline Blood urea nitrogen (mg/dL) & 31 & $5-18$ \\
\hline Creatinine $(\mathrm{mg} / \mathrm{dL})$ & 0.23 & \\
\hline Aspartate aminotransferase (IU/L) & 37 & \\
\hline Alanine aminotransferase (IU/L) & 21 & \\
\hline Sodium (mmol/L) & 142 & $135-145$ \\
\hline Potassium (mmol/L) & 4 & $3.5-5.5$ \\
\hline Antistreptolysin-O titer (Todd units) & 161 & $120-160$ \\
\hline Rapid group A streptococcal antigen test & Negative & \\
\hline Throat culture test & Negative & \\
\hline Stool culture test & Negative & \\
\hline Stool rotavirus antigen & Positive & \\
\hline Stool adenovirus antigen & Negative & \\
\hline \multicolumn{3}{|l|}{ Rubella antibodies, serum } \\
\hline $\operatorname{IgM}$ & Negative & \\
\hline $\operatorname{IgG}$ & Positive & \\
\hline \multicolumn{3}{|l|}{ Rubeola antibodies, serum } \\
\hline $\operatorname{IgM}$ & Negative & \\
\hline $\operatorname{IgG}$ & Positive & \\
\hline \multicolumn{3}{|l|}{ Epstein-Barr virus antibodies, serum } \\
\hline Early antigen (EA) & Negative & \\
\hline VCA IgM & Negative & \\
\hline VCA IgG & Positive & \\
\hline EBNA (IgG) & Positive & \\
\hline \multicolumn{3}{|l|}{ Cytomegalovirus antibodies, serum } \\
\hline $\operatorname{IgM}$ & Negative & \\
\hline $\operatorname{IgG}$ & Positive & \\
\hline
\end{tabular}

in stool samples and that other potential etiologic factors were ruled out we conclude that the skin eruptions were associated with rotavirus infection. An exanthem is a self-limited lesion usually associated with a viral infection and which, by itself, is not an issue of substantial concern. The prognosis depends on the clinical progress of the enteric symptoms. Routine rotavirus vaccination may prevent the occurrence of complications such as described in this report. ${ }^{17}$ 
Finally, rotavirus infection should be assessed in the differential diagnosis of children with erythematous eruption.

\section{REFERENCES}

1. Glass RI, Parashar UD, Bresee JS, Turcios R, et al. Rotavirus vaccines: current prospects and future challenges. Lancet 2006;368:323-32.

2. Treanor J, Hirsch M, Baron E. Clinical presentation and diagnosis of rotavirus infection. www.uptodate.com. Last updated: Jan 17, 2013.

3. Gastroenteritis por Rotavirus y su prevención. Buenos Aires: Comisiones y comités SAP 2006;104(6).

4. Akelma AZ, Kutukoglu I, Koksal T, Cizmeci MN, et al. Serum transaminase elevation in children with rotavirus gastroenteritis: seven years' experience. Scand J Infect Dis 2013;45:362-7.

5. Nishimura S, Ushijima H, Shiraishi H, Kanazawa C, et al. Detection of rotavirus in cerebrospinal fluid and blood of patients with convulsions and gastroenteritis by means of the reverse transcription polymerase chain reaction. Brain Dev 1993;15:457-9.

6. Pang XL, Joensuu J, Vesikari T. Detection of rotavirus RNA in cerebrospinal fluid in a case of rotavirus gastroenteritis with febrile seizures. Pediatr Infect Dis J 1996;15:543-5.

7. Yoshida A, Kawamitu T, Tanaka R, Okumura M, et al. Rotavirus encephalitis: detection of the virus genomic RNA in the cerebrospinal fluid of a child. Pediatr Infect Dis J 1995;14:914-6.
8. Santosham M, Yolken RH, Quiroz E, Dillman L, et al. Detection of rotavirus in respiratory secretions of children with pneumonia. J Pediatr 1983;103:583-5.

9. Limbos MA, Lieberman JM. Disseminated intravascular coagulation associated with rotavirus gastroenteritis: report of two cases. Clin Infect Dis 1996;22:834-6.

10. Takahashi S, Oki J, Miyamoto A, Koyano S, et al. Encephalopathy associated with haemophagocytic lymphohistiocytosis following rotavirus infection. Eur J Pediatr 1999;158:133-7.

11. Gilger MA, Matson DO, Conner ME, Rosenblatt HM, et al. Extraintestinal rotavirus infections in children with immunodeficiency. J Pediatr 1992;120:912-7.

12. Ruzicka T, Rosendahl C, Braun-Falco O. A probable case of rotavirus exanthem. Arch Dermatol 1985;121:253-4.

13. Di Lernia V, Lombardi M, Lo Scocco G. Infantile acute hemorrhagic edema and rotavirus infection. Pediatr Dermatol 2004;21:548-50.

14. Di Lernia V. Gianotti-Crosti syndrome related to rotavirus infection. Pediatr Dermatol 1998;15:485-6.

15. Sugata K, Taniguchi K, Yui A, Miyake F, et al. Analysis of rotavirus antigenemia and extraintestinal manifestations in children with rotavirus gastroenteritis. Pediatrics 2008;122:392-7.

16. Di Lernia V, Ricci C. Skin manifestations with Rotavirus infections. Int J Dermatol 2006;45:759-61.

17. Maton D. Rotavirus vaccines for infants. www.uptodate. com. Last updated: Sep 20, 2013. 